\title{
Mandenkan
}

MANDENIKAN Bulletin semestriel d'études linguistiques mandé

\section{Some notes on the encoding of property concepts in Vai from a typological and comparative Central Mande perspective}

Quelques notes sur l'expression des qualities en Vai dans une perspective

typologique et comparée du Mandé Central

НЕКОТОРЫЕ ЗАМЕЧАНИЯ ОТНОСИТЕЛЬНО ВЫРАЖЕНИЯ КАЧЕСТВЕННЫХ

ЗНАЧЕНИЙ В ВАИ, В ТИПОЛОГИЧЕСКОЙ И СРАВНИТЕЛЬНОЙ ПЕРСПЕКТИВЕ

\section{Holger Tröbs}

\section{(2) OpenEdition}

Journals

Electronic version

URL: https://journals.openedition.org/mandenkan/347

DOI: 10.4000/mandenkan.347

ISSN: 2104-371X

\section{Publisher}

Llacan UMR 8135 CNRS/Inalco

\section{Printed version}

Date of publication: 1 December 2014

Number of pages: 111-130

ISSN: 0752-5443

\section{Electronic reference}

Holger Tröbs, "Some notes on the encoding of property concepts in Vai from a typological and comparative Central Mande perspective", Mandenkan [Online], 52 | 2014, Online since 01 December 2014, connection on 08 July 2021. URL: http://journals.openedition.org/mandenkan/347 ; DOI: https:// doi.org/10.4000/mandenkan.347

This text was automatically generated on 8 July 2021.

Les contenus de Mandenkan sont mis à disposition selon les termes de la Licence Creative Commons Attribution - Pas d'Utilisation Commerciale - Partage dans les Mêmes Conditions 4.0 International. 


\section{Some notes on the encoding of property concepts in Vai from a typological and comparative Central Mande perspective}

Quelques notes sur l'expression des qualities en Vai dans une perspective

typologique et comparée du Mandé Central

НЕКОТОРЫЕ ЗАМЕЧАНИЯ ОТНОСИТЕЛЬНО ВЫРАЖЕНИЯ КАЧЕСТВЕННЫХ

ЗНАЧЕНИЙ В ВАИ, В ТИПОЛОГИЧЕСКОЙ И СРАВНИТЕЛЬНОЙ ПЕРСПЕКТИВЕ

Holger Tröbs

\section{AUTHOR'S NOTE}

This article is based on a paper read at the $4^{\text {th }}$ International Conference on Mande Languages and Linguistics, Bobo-Dioulasso, September 15-17, 2014.

\section{Abbreviations}

$\mathrm{ADJ}=$ adjective

ADV.COMP $=$ adverbial complement

$\mathrm{COP}=$ copula

$\mathrm{DEF}=$ definite marker

$\mathrm{FACT}=$ factative

IPFV = imperfective

$\mathrm{L}=$ low tone replacing the stem tone of any verbs

Loc.COP = locative copula

IPFV = imperfective

$\mathrm{NEG}=$ negation

$\mathrm{NP}=$ noun phrase

$\mathrm{O}=$ object 
PART.RES = resultative participle

$\mathrm{PL}=$ plural

$\mathrm{PM}=$ predicative marker

$\mathrm{PN}=$ predicate noun

$\mathrm{Pp}=\mathrm{S}$

postposition $=$ subject

$\mathrm{SG}=$ singular

$\mathrm{VS}=$ verb stem

$\varnothing=$ absence of PM

\section{Introduction}

1 Vai is a Central Mande language spoken along the northwestern coast of Liberia, but also extending into Sierra Leone (Welmers 1976: 1). The Ethnologue-16 (Lewis 2009) gives the number of Vai speakers as 119,500. Vai belongs to the Manding-Jogo branch within the Central Mande languages (cf. Kastenholz 1996: 70f.). Its nearest relative is Kono, which is spoken in Sierra Leone.

2 Stassen (1997) has argued that, viewed from a cross-linguistic perspective, the encoding of property concepts in Vai represents an extreme case in that Vai makes use of four different encoding strategies, two non-verbal strategies (i.e., one nominal, one locational) and two verbal strategies. The prototypical feature of the nominal strategy is a nonverbal copula or, as Stassen (1997: 612) puts it, "a nonverbal supportive item". An example of the use of the nominal strategy for property concepts in Vai is presented in (1).

\begin{tabular}{|l|l|l|l|}
\hline (1) & \multicolumn{2}{|l|}{ Vai [= nominal strategy featuring the nonverbal copula mù] } \\
\hline & $\grave{a}$ & lólì & mù. \\
\hline & 3 SG & young & COP \\
\hline & 'He is young.' (Welmers 1976: 75) \\
\hline
\end{tabular}

3 The locational strategy is also typically characterized by the presence of a supportive item, but, in contrast to the nominal strategy, by "a supportive item which has the morphosyntactic characteristics of a verb" (Stassen 1997: 55). Example (2) illustrates the use of the locational strategy for property concepts in Vai, which is featured by the locative copula $6 \dot{\varepsilon}$.

\begin{tabular}{|l|l|l|l|}
\hline (2) & \multicolumn{3}{|l|}{ Vai [= locational strategy featuring the defective verbal copula $6 \grave{\varepsilon}]$} \\
\hline & $\grave{a}$ & $6 \grave{\varepsilon}$ & làà. \\
\hline & 3 SG & Loc.COP & light \\
\hline & \multicolumn{2}{|l}{ 'It is light (in weight).' (Welmers 1976: 77) } \\
\hline
\end{tabular}


The cognate forms of the locative copulas belonging to the BE-type found in Vai and Manding are thus considered by Stassen (1997: 95) as defective existential verbs, which, at some historical level, have lost their verbal properties (for a detailed discussion of this point, cf. Tröbs 2009: Section 8.4.2).

5 The verbal strategy typically allows independent, non-supported encoding of predicates and does thus not contain supportive items such as copulas or auxiliaries (Stassen 1997: 42). The two verbal encoding types employed for property concepts in Vai are illustrated in (3) and (4).

\begin{tabular}{|c|c|c|}
\hline \multirow[t]{2}{*}{ (3) } & \multicolumn{2}{|c|}{ Vai [= verbal strategy, factative construction marked by the suffix $\left.-(l) \grave{a}^{1}\right]$} \\
\hline & lùmbólòě & lóla-(l)à \\
\hline & orange.DEF & be.sour-FACT \\
\hline & \multicolumn{2}{|c|}{ 'The orange is sour.' (Welmers 1976: 84) } \\
\hline
\end{tabular}

\begin{tabular}{|l|l|l|}
\hline (4) & \multicolumn{2}{|c|}{ Vai [= verbal strategy, stative construction marked by low tone] } \\
\hline & kàí̌̌ & jày \\
\hline & man.DEF & be.tall.STATIVE \\
\hline & 'The man is tall.' (Welmers 1976: 95) \\
\hline
\end{tabular}

6 In my paper, I would like to elaborate on the encoding of property concepts in Vai from a typological and a comparative Central Mande perspective. More specifically, I shall focus on four points:

1. The four encoding strategies for property concepts will be illustrated and analyzed against the theoretical background of two functional-typological approaches, namely Dixon's (1977) pioneering survey on the morphosyntax and semantics of adjectives as well as Stassen's (1997) typological study on intransitive predication.

2. The verbal encoding strategies for property concepts will be discussed from a Central Mande perspective.

3. By exploring the verbal encoding behaviour of property concepts in Vai the empirical base for a typology of quality (stative) verbs in Mande will be broadened.

4. Finally, Stassen's (1997: 30) so-called Adjective Principle which claims that property concepts (predicative adjectives) have no encoding strategy of their own will be disproved by data from different Central Mande and Northwestern Mande languages.

7 My presentation is mainly based on Welmers' grammar of Vai (1976), but also on earlier grammatical descriptions such as those of Heydorn (1971, published posthumously from a manuscript of 1934) and Klingenheben $(1924 / 25,1933)$ as well as Klingenheben's collection of Vai lexical data adapted and edited by Raimund Kastenholz (unpublished manuscript). 


\section{Theoretical background}

\subsection{Dixon 1977}

8 A fundamental approach to the conceptual domain of property concepts has been offered by Dixon (1977) in terms of semantic types. Dixon (1977) explored the systematic correlation between the word class "adjective" as defined by morphosyntactic criteria and basic semantic types in 17 languages. Dixon worked from the assumption "that the syntactic properties of a lexical item can largely be predicted from its semantic description" (1977: 24). According to Dixon (1977: 31), there are seven semantic types that form the word class of adjectives.

Core semantic types (Dixon 1977: 31)

\begin{tabular}{|l|l|}
\hline 1. Dimension & big, large, little, small, long, short, thick, thin, etc. \\
\hline 2. Age & old, young, new \\
\hline 3. Value & good, bad, fine, excellent, proper, etc. \\
\hline 4. Color & black, white, red, etc. \\
\hline
\end{tabular}

Peripheral semantic types (Dixon 1977: 31)

\begin{tabular}{|l|l|}
\hline 5. Physical property & hard, soft, heavy, light, hot, cold, sweet, sour, etc. \\
\hline 6. Human propensity & jealous, happy, kind, clever, rude, proud, etc. \\
\hline 7. Speed & fast, slow, quick, etc. \\
\hline
\end{tabular}

Dixon's survey discovered universal tendencies that govern the morphosyntactic behaviour of the semantic types mentioned above. The four core semantic types prototypically belong to languages with a small closed adjective class whereas in languages with a large open adjective class this class consists of all or most of the members of all seven semantic types (Dixon 1977: 55). In his later study on adjective classes in typological perspective Dixon (2004: 5) established some additional semantic types such as "Difficulty" ('easy', 'difficult', 'hard', 'simple', etc.) and "Similarity" ('similar', 'different', etc.). These additional semantic types are associated with languages disposing of very large adjective classes.

Finally, Dixon's (1977) survey reveals that in contrast to the two major word classes "nouns" and "verbs", the word class "adjective" cannot be identified on morphosyntactic grounds in many languages. In other words, semantically adjectival lexemes (i.e., words denoting property concepts) can be affiliated either with verbs or nouns by sharing of the same morphosyntactic behaviour with one or the other of those two major word classes. 


\subsection{Stassen 1997}

11 Another fundamental approach which advocates the hybrid status of adjectives (property concept words) as a word class with respect to their categorial affiliation has been offered by Stassen (1997). In his extensive study on intransitive predication (based on a sample of 410 languages) Stassen explores the encoding strategies of four types of intransitive predicates: event, class-membership, locational, and property concepts. Each of the four types is typically associated with a specific word class, that is, verb, noun, adverbial, and adjective respectively. Among these four types the property concept typically represented by an adjective is the most problematic predicate type in terms of identification. The same holds true for the treatment of adjectives as a universal word class (cf. Dixon 1977; 2004; Croft 1990; Creissels 2003). Stassen (1997: 16-17), following Givón (1984), draws upon the intermediate, non-focal position of property concepts on the Time Stability Scale whose two extreme ends are formed by events and classes. Stassen, thus, claims that "property concept predicates do not form a universal, homogeneous, cognitive category in the same way as events or classes" (1997: 17). According to Stassen, property concepts can be defined cross-linguistically on the basis of the following features.

Definition of property-concept predicates (Stassen 1997: 17)

A prototypical property concept predicate is a predicate which

(a) is intermediately time stable;

(b) is non-volitional; and

(c) does not refer to kinds.

Feature (a) relates to the position on the Time Stability Scale, feature (b) distinguishes properties from states, and feature (c) properties from class-membership.

With regard to the encoding behaviour of property concepts, Stassen argues that predicative adjectives (property concept predicates) have no prototypical encoding strategy of their own, rather they are aligned with verbs, nominals or locationals in terms of their formal encoding and, as a result, have a verbal, nominal or locational strategy. Thus, Stassen (1997: 30) claims that no language has an encoding strategy used exclusively for property concept predicates. To account for this fact, he proposes the so-called Adjective Principle:

The Adjective Principle (Stassen 1997: 30)

Predicative adjective have no prototypical encoding strategy of their own. In their predicative encoding, adjectives will align themselves either with verbs (and, as a result, have a verbal strategy), or with nominals, or with locationals. In no language is it possible to have an encoding strategy which is used exclusively for predicative adjectives.

\section{Identification of the main word classes "noun", "verb" and "adjective" in Vai}

Before starting to examine the encoding strategies used for the expression of property concepts in Vai in detail, I shall briefly comment on the identification of the main word classes "noun", "verb" and "adjective" in Vai.

Nouns in Vai can be morphologically identified as lexical units taking two kinds of determiners: the definite marker $-\check{\varepsilon}$ and plural marker nú (cf. Welmers 1976: 30, 45). They can be syntactically identified as lexical units functioning as head of a phrase. In 
distributional terms, they appear in presentational identificational clauses (NP + copula mù; cf. bă mù 'it's a goat').

Verbs in Vai can be formally identified as lexical units occurring with a particular set of suffixes (e.g. -(l)à in the future) or with a low tone replacing its stem tone. This tonal replacement is itself considered a suffix (Welmers 1976: 79).

With regard to the definition of adjectives, this class is seen as a word class that is grammatically distinct from the noun and verb class and which, following Sasse (1993: 661), "prototypically serves the attribution of properties to individuals". Thus, adjectives in Vai are narrowly defined by the following criteria: ${ }^{2}$

- they function as modifier (attribute) to a noun in an NP

- they cannot be conjugated (in opposition to verbs)

- they cannot function as head of a phrase (in opposition to nouns)

According to this definition, two subclasses of underived adjectives could be identified: a very small subclass of adjectives which has only a modifying (attributive) function (i.e., bélè 'good', 'nice', mésć '(very) small', nyàmá 'tall') and a larger subclass of adjectives which has a modifying (attributive) as well as a predicative functions (see Section 4.1 and 4.2).

\section{The non-verbal encoding of property concepts in Vai}

As noted before, Vai employs two non-verbal strategies, a nominal as well as a locational encoding with a number of property concept words (adjectives). The nonverbal predication pattern in Vai are summarized in Table 1.

Table 1. Nonverbal predication pattern in Vai

\begin{tabular}{|c|c|c|}
\hline & Affirmative & negative \\
\hline $\begin{array}{l}\text { Identification } \\
\text { (presentational value) }\end{array}$ & $\mathrm{NP}+$ mù & NP + máà \\
\hline $\begin{array}{l}\text { Identification } \\
\text { (class-membership / equation } \\
\text { and } \\
\text { predication of properties) }\end{array}$ & $\begin{array}{l}\mathrm{NP}+\mathrm{NP}+\mathrm{mù} \\
{[\mathrm{S}+\mathrm{PN}+\mathrm{COP}]} \\
\mathrm{NP}+\mathrm{mù}+\mathrm{NP}+(\mathrm{l}) \mathrm{à} \\
{[\mathrm{PN}+\mathrm{COP}+\mathrm{S}+\mathrm{Pp}]} \\
\underline{\mathrm{NP}+\mathrm{ADJ}+\mathrm{mù}} \\
\underline{\mathrm{NP}+\mathrm{PART} \cdot \mathrm{RES}+\mathrm{mù}}\end{array}$ & $\begin{array}{l}\mathrm{NP}+\mathrm{NP}+\text { máà } \\
\mathrm{NP}+\text { máà + NP + (l)à } \\
\frac{\mathrm{NP}+\mathrm{ADJ}+\text { máà }}{\mathrm{NP}+\mathrm{PART} \cdot \mathrm{RES}+\text { máà }}\end{array}$ \\
\hline $\begin{array}{l}\text { Location } \\
\text { (locative relations and } \\
\text { predication of properties) }\end{array}$ & $\begin{array}{l}\mathrm{NP}+6 \grave{\varepsilon}+\mathrm{NP}+\mathrm{Pp} \\
{[\mathrm{S}+\text { Loc.COP + ADV.COMP] }} \\
\mathrm{NP}+6 \grave{\varepsilon}+\mathrm{ADJ}\end{array}$ & 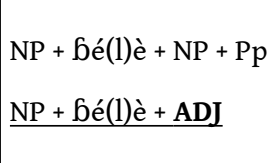 \\
\hline
\end{tabular}

BASED ON WELMERS 1976: 74-78.

21 Table 1 shows a two-way category split of adjectives in Vai, in that one subclass of adjectives is always encoded nominally, and a second subclass is always encoded 
locationally. I shall now examine the property concept words employed with each of the two non-verbal strategies in greater detail.

\subsection{The nominal strategy}

Vai has two alternative constructions for expressing class-membership and equation. The first consists of a subject followed by a predicate nominal and the copula mù, as shown in (5). The second construction type is structured as follows: Predicate nominal + Copula + Subject + relational noun / postposition (6).

\begin{tabular}{|c|c|c|c|c|c|}
\hline (5) & $\eta$ & ygój̀, & kòlà & léć-mòગ̀ & mù. \\
\hline & $1 \mathrm{SG}$ & older.brother & cloth & weave-person & COP \\
\hline & & er & & (Welmers & 76: 131 \\
\hline
\end{tabular}

\begin{tabular}{|l|l|l|l|l|l|}
\hline (6) & Vaims & $m u$ & $i$ & $l a$. & \\
\hline & Vaiman & COP & $2 S G$ & Pp & \\
\hline \multicolumn{7}{|c|}{ 'You are a Vaiman.' (Heydorn 1971: 183) } \\
\hline
\end{tabular}

23 The predicate nominal strategy is also employed with a very small group of underived adjectives, as shown in Table 2. Two of them ('new', 'young') belong to the semantic type "age", the other two ('unripe', 'fresh' / 'raw') belong to the semantic type "physical property". In the examples shown in Table 2, the property concept word is preceded by a noun or by the stem form of a pronoun, and followed by the copula mù.

Table 2. Property words (underived adjectives) used with the nominal strategy

\begin{tabular}{|l|l|}
\hline námà 'new' & sámbàà námà mù 'the basket is new' \\
\hline lólì 'young' & à lólì mù 'he is young' \\
\hline bùlú 'unripe' & lùmbólòe bùlú mù 'the orange is unripe' \\
\hline kúlà 'fresh, raw' & à kúlà mù 'it (fish / meat) is fresh / raw' \\
\hline
\end{tabular}

\section{BASED ON WELMERS 1976: 75.}

Moreover, the predicate nominal strategy is used in general for the encoding of resultative participles, that is, for verbal adjectives derived from process verbs by means of the suffix -le yielding a resultative meaning with present time reference, $c f$. Table 3. 
Table 3. Property words (resultative participles) used with the nominal strategy

\begin{tabular}{|l|l|}
\hline kilá ‘become sick' & kàí̌ kilà-lé mù 'the man is sick' \\
\hline dhógbò 'become wet' & kòláă dhógbò-lé mù 'the cloth is wet' \\
\hline màló 'become ashamed' & à màlò-lé mù 'he is ashamed' \\
\hline
\end{tabular}

\section{BASED ON WELMERS 1976: 75.}

\subsection{The locational strategy}

Locative relations are expressed by a locative copula $6 \dot{\varepsilon}$ and an adverbial phrase containing a noun phrase followed by a locative relational noun or postposition.

\begin{tabular}{|c|c|c|c|c|}
\hline \multirow[t]{2}{*}{ (7) } & kàlááa & $6 \grave{\varepsilon}$ & sě̄ě & mà. \\
\hline & snake.DEF & Loc.COP & rock.DEF & surface \\
\hline & 'The snake & on the & .' (Welm & 1976: 48) \\
\hline
\end{tabular}

The locational strategy is used with a small number of underived adjectives, as shown in Table 4. The adjectives belong to various semantic types comprising core semantic types as well as peripheral semantic types (cf. 'short', 'thin' = "dimension"; 'flexible', 'light (in weight)' = "physical property”; 'different' = "similarity”).

Table 4. Property words (underived adjectives) used with the locational strategy

\begin{tabular}{|c|c|}
\hline kúndú 'short' & $\begin{array}{l}\text { kàié } 6 \dot{\varepsilon} \text { kúndú 'the man is short' } \\
\text { à Gélè kúndú 'he isn't short' }\end{array}$ \\
\hline léf'́ ‘thin’ & à $b \grave{\varepsilon}$ léfé 'it is thin (as sheet metal)' \\
\hline lèkpغ̀ 'flexible' & 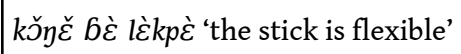 \\
\hline làà 'light' & à $b \dot{\varepsilon}$ làà 'it is light (in weight)' \\
\hline gbà 'different' & à $b \grave{\varepsilon} g b a ̀$ 'it is different' \\
\hline
\end{tabular}

WELMERS 1976: 77.

It should be noted that qualificative ideophones are also used in locative constructions.

\begin{tabular}{|l|l|l|l|}
\hline (8) & kilàa & b̀̀ & còicòi \\
\hline & road.DEF & Loc.COP & muddy.mess \\
\hline
\end{tabular}


'The road is muddy mess.' (Welmers 1976: 77)

\subsection{Discussion} of property concepts. The verbal predication pattern in Vai are summarized in Table 5.

Table 5. Verbal predications pattern in Vai

\begin{tabular}{|l|l|l|}
\hline & affirmative & negative \\
\hline $\begin{array}{l}\text { Present } \\
\text { [Progressive }]\end{array}$ & $\mathrm{S}+6 \grave{\varepsilon}+(0)+$ VS-nà & S + Gé(l)è + (0) + VS-nà \\
\hline $\begin{array}{l}\text { Incompletive } \\
\text { [Habitual] }\end{array}$ & $\mathrm{S}+\grave{\text { I }}+(\mathrm{O})+$ VS-L & S + wé(l)è + (0) + VS-L \\
\hline
\end{tabular}




\begin{tabular}{|c|c|c|}
\hline Future & NP + ì + (0) + VS-(l)à & $\begin{array}{l}\text { NP + wé(l)è + (0) + VS- } \\
\text { (l)à }\end{array}$ \\
\hline $\begin{array}{l}\text { Incompletive } \\
\text { [Hortative] }\end{array}$ & $S+\grave{i}+(0)+V S-L$ & $\mathrm{~S}+$ má + (0) + VS-L \\
\hline Conditional & S + (l)à + (O) +VS-(l)éè & $\mathrm{S}+$ má $+(\mathrm{O})+\mathrm{VS}-\mathrm{L}$ \\
\hline $\begin{array}{l}\text { Completive } \\
\text { [Perfect/ } \\
\text { Perfective] }\end{array}$ & S + (l)à + (O) +VS-L & S + má + (O) + VS-L \\
\hline Factative & 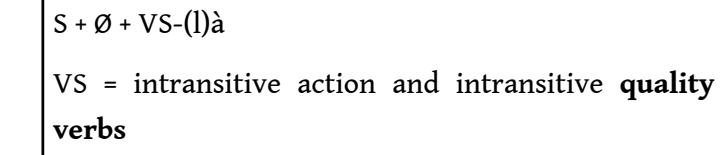 & $\begin{array}{l}\text { S + má + VS-L } \\
\text { [= perfect / perfective }]\end{array}$ \\
\hline Stative & $\begin{array}{l}S+\emptyset+V S-L \\
V S=\text { small number of intransitive quality verbs }\end{array}$ & $\begin{array}{l}\text { S + má + VS-L } \\
\text { [= perfect / perfective }]\end{array}$ \\
\hline
\end{tabular}

Based on Welmers 1976: 79-96³.

Table 5 shows that both verbal construction types (the factative and the stative construction) are only used with intransitive verbs and make no use of predicative markers. The negation of both construction types is identical with the negation pattern of the perfect/perfective. I shall now examine the quality verbs exclusively used either in the factative or in the stative construction in greater detail.

\subsection{Quality verbs and the factative construction}

Some of the verbally encoded property predicates always occur in the so-called factative construction (cf. Welmers 1973: 346). This construction is characterized by the verbal suffix -(l)à, while the verb stem keeps its lexical tone with no alternations. After verb stems ending in $\eta$, the stem-final $y$ combines with the initial (l) of this suffix as an intervocalic $n d$. When used with action verbs, the factative construction has simply past time reference without looking at the situation in terms of its results or consequences.

\begin{tabular}{|l|l|l|}
\hline$(9)$ & $\eta$ & kúnć-(l)à. \\
\hline & 1 SG & wake.up-FACT \\
\hline $\begin{array}{l}\text { 'I woke up.' (with no implication that the speaker stayed awake after that time) } \\
\text { (Welmers 1976: 82) }\end{array}$ \\
\hline
\end{tabular}

By contrast, with quality verbs the factative has present time reference (Welmers 1976: 82-83), as shown in Table 6. 
Table 6. Quality verbs occurring in the factative

\begin{tabular}{|c|c|}
\hline$k p \varepsilon ́$ 'be white' & kòláă kpé-(l)à 'the cloth is white' \\
\hline fín 'be black' & kòláă finda 'the cloth is black' \\
\hline jă 'be red' & kòláă jă-(l)à 'the cloth is red' \\
\hline nóó ‘be dirty’ & kòláă nóó-(l)à ‘the cloth is dirty’ \\
\hline$z \varepsilon ́ n \dot{\varepsilon}$ 'be clean' & kòláă mèć zénc̀-(l)à 'the cloth is clean' \\
\hline kónà 'be bitter' & bóliě kónà-(l)à ‘the medicine is bitter’ \\
\hline kímà 'be cold' & jič kímà-(l)à 'the water is cold' \\
\hline lólà 'be sour' & lùmbólòe lóla-(l)à 'the orange is sour' \\
\hline tây 'be straight' & kذ̀y mè $\varepsilon$ tândà 'this stick is straight' \\
\hline tòó 'be fat' & kài mènúú tòó-(l)à 'that man is fat' \\
\hline tùlú 'be fat, greasy, oily' & à tùlú-(l)à 'it (meat, animal) is fat' \\
\hline tíndí 'be valuable, oriented' & kàí mèć tíndì-(l)à 'this man is valuable' \\
\hline kpóóli ‘be smooth’ & à kpóóli-(l)à 'it is smooth' \\
\hline kúndá 'be bent, crooked' & à kúndá- $(l) \grave{a}$ 'it is bent' \\
\hline kínyá 'be tasty, agreeable' & à kínyá-(l)à 'it is tasty' \\
\hline
\end{tabular}

BASED ON WELMERS 1976: 82-83; KUZNETSOVA 2004: 10; KASTENHOLZ, MS.

The quality verbs occurring in the factative belong predominantly to the semantic types "color" and "physical property".

\subsection{Quality verbs and the stative construction}

37 Another small group of verbally encoded property concepts always appear in the socalled stative form, which is marked by low tone (Welmers 1976: 95). This group contains eight quality verbs as well as two modal verbs, as shown in Table 7.

Table 7. Quality verbs occurring in the stative

\begin{tabular}{|l|l|}
\hline kòsá 'be able (acquired ability)' & $\begin{array}{l}\text { à kòsa wúndé málà 'he can cook' } \\
\text { (lit., 'he can cooking do') }\end{array}$ \\
\hline kúy 'be able (native ability)' & $\begin{array}{l}\eta \text { kúy à málà í yè 'I can do it for you' } \\
\text { (lit., 'I can it do you for') }\end{array}$ \\
\hline
\end{tabular}




\begin{tabular}{|c|c|}
\hline kòlò 'be large, be wide' & kéyદ̌ kòlò 'the house is large' \\
\hline lذ̀̀̀ ‘be small, be narrow’ & kéyč lòj̀ 'the house is small’ \\
\hline jày 'be tall' & kàiž jày 'the man is tall' \\
\hline kpغ̀lè 'be hard' & kכ̌yと̌ lò kpغ̀lè 'the wood is hard' \\
\hline nyì 'be fine' & kénĚ nyì 'the house is fine' \\
\hline jáò 'be bad' & kilàă jáò 'the road is bad' \\
\hline námàà ‘be slippery’ & kilàă námàà 'the road is slippery' \\
\hline fànyá 'be heavy' & à fànyá 'it is heavy' \\
\hline
\end{tabular}

Welmers 1976: 95, $98^{4}$.

The quality verbs occurring in the stative belong to three semantic types, i.e., "dimension", "value" and "physical property".

Furthermore, in addition to the ten forms occurring in the stative recorded by Welmers (1976), older sources such as Klingenheben's collection of Vai lexical data (cf. Kastenholz, Ms) and Heydorn (1971: 173) mention a few more forms such as ló 'to say (that)' and fàní 'to lie, to tell lies (as a habit)' (cf. also Kuznetsova 2004: 11).

\subsection{Quality verbs and the formation of resultative participles}

It is interesting to note that the two groups of quality verbs show a different behavior with regard to the suffixation of the resultative marker -lé. Quality verbs occurring in the stative construction need first to obtain a dynamic reading by adding the suffix -yáa deriving inchoative/causative verbs in order to admit the application of the resultative suffix -lé. Thus, these verbs only have a stative reading.

Table 8. Formation of resultative participles from quality verbs used in the

\begin{tabular}{|c|c|c|}
\hline kòlò 'be large' & kòlòyáà ‘become larger’ & kòlòyáà-lé 'large' \\
\hline lòj̀ ‘be small’ & lòj̀yáà 'become smaller' & lòj̀yáà-lé ‘small’ \\
\hline jày 'be tall' & jànjáá 'become taller’ & jànjáà-lé 'tall’ \\
\hline kpغ̀lè 'be hard; & kpèlèyáà 'become harder' & kpèlèyáà-lé 'hard' \\
\hline nyi 'be fine' & nyía 'become fine' & nyíà-lé 'fine' \\
\hline fànyá 'be heavy' & fànyáà ‘become heavy’ & fànyáà-lé 'heavy' \\
\hline
\end{tabular}

STATIVE (BASED ON WELMERS 1976: 67, 80 AND HEYDORN 1971: 180-181). 
41 By contrast, quality verbs appearing in the factative construction may directly be suffixed with -lé. Thus, these verbs seem to conflate two readings: a stative reading and a change of state reading.

Table 9: Formation of resultative participles from quality verbs used in the factative

\begin{tabular}{|c|c|}
\hline nóó ‘be(come) dirty’ & nóó-lé ‘dirty’ \\
\hline zÉnc̀ ‘be(come) clean’ & zÉnc̀-lé 'clean' \\
\hline kónà ‘be(come) bitter’ & kóná-lé 'bitter' \\
\hline kímà 'be(come) cold' & kímá-lé 'cold' \\
\hline lólà ‘be(come) sour' & lólá-lé ‘sour’ \\
\hline tây 'be(come) straight' & tândé 'straight' \\
\hline tòó ‘be(come) fat’ & tòj̀-lé ‘fat' \\
\hline tùlú ‘be(come) fat, greasy, oily’ & tùlú-lé 'fat, greasy, oily' \\
\hline tíndí 'be(come) valuable, oriented' & tíndí-lé 'valuable, oriented' \\
\hline kpóóli ‘be(come) smooth’ & kpóóli-lé ‘smooth’ \\
\hline kúndá 'be(come) bent, crooked' & kúndá-lé 'bent, crooked' \\
\hline kínyá ‘be(come) tasty, agreeable’ & kínyá-lè 'tasty, agreeable' \\
\hline
\end{tabular}

BASED ON WELMERS 1976: 66-67; HEYDORN 1971: 180-181; KASTENHOLZ, MS.

\subsection{Discussion}

42 I shall now discuss the Vai data on the verbal strategies for property concepts from a comparative Central Mande perspective. In contrast to Vai, most other Central Mande languages exclusively use either a so called factative or a special stative construction for the predicative encoding of property concepts.

43 As noted by Lüpke (2005: 97), Yalunka exclusively has a so-called factative or "zeromarked" construction for property concept words. As in Vai, this construction makes no use of predicative markers, but in contrast to Vai, the verb stem is zero-marked (and does thus not show any tonal alternation or suffixation). With quality verbs (or stative verbs in Lüpke's terminology, for a discussion of this point, see Section 6), the default tense/aspect interpretation is present/imperfective, while all other verbs convey a past/perfective meaning (Lüpke 2005: 120), as illustrated in the following two examples. In (10), the zero-marked quality verb melun 'be pointed' has a present tense interpretation and is thus compatible with the temporal adverb xori 'now', whereas the dynamic verb faa 'to come' in (11) receives a past perfective interpretation and does not admit the temporal adverb xori 'now'. 


\begin{tabular}{|l|l|l|}
\hline$(10)$ & Yalunka \\
\hline & krEJn-na & melun. \\
\hline & pencil-DEF & be.pointed \\
\hline & 'The pencil is pointed.' (Lüpke 2005: 64, 158) \\
\hline
\end{tabular}

\begin{tabular}{|l|l|l|}
\hline$(11)$ & Yalunka \\
\hline & e & \multicolumn{2}{l|}{ faa. } \\
\hline & 3PL & come \\
\hline & \multicolumn{2}{|l|}{ 'They came.' (Lüpke 2005: 64, 149) } \\
\hline
\end{tabular}

44 Moreover, Lüpke (2005: 158) observes that quality verbs in Yalunka are not exclusively stative - most of them can be used with the imperfective marker. As shown in (12), the quality verb melun 'be pointed' conveys a change-of-state reading when used in the imperfective. Quality verbs in Yalunka thus conflate a stative and a change of state reading. A similar behavior has been argued for quality verbs in Vai which appear in the factative construction on the basis of their formation of resultative participles (see Section 5.3).

\begin{tabular}{|l|l|l|l|l|l|l|}
\hline (12) & \multicolumn{4}{|l|}{ Yalunka } & \\
\hline & tumb- $\varepsilon \varepsilon$ & melon-ma & $a$ & xere & nan & na \\
\hline & thorn-DEF & be.pointed-IPFV & 3 SG & youth & FOC & with \\
\hline & \multicolumn{5}{|l}{ 'It's in its young age that a thorn becomes pointed.' (Lüpke 2005: 158) } \\
\hline
\end{tabular}

On the other hand, most members of the Manding-Mokole sub-branch have a special stative construction for the predicative encoding of property concepts, but lack a so called factative construction.

As in Vai, the stative constructions found in the Mokole cluster (i.e., in Mogofin, Koranko and Lele) make no use of predicative markers, but in contrast to Vai, the verb stem does not show any tonal alternation or suffixation.

\begin{tabular}{|c|c|c|c|}
\hline \multirow[t]{2}{*}{ (13) } & \multicolumn{3}{|l|}{ Koranko } \\
\hline & yilk & (Ø) & wùru. \\
\hline & rope.DEF & (PM) & be.short \\
\hline & \multicolumn{3}{|c|}{ 'The rope is short.' (Kastenholz 1987: 110) } \\
\hline
\end{tabular}


47 In contrast to Vai, most stative constructions found in the Manding language/dialect cluster make use of a predicative marker, as shown for Xasonga. ${ }^{5}$

\begin{tabular}{|l|l|l|l|}
\hline$(14)$ & \multicolumn{3}{|l|}{ Xasonga } \\
\hline & Ginta & $x a$ & bete. \\
\hline & Ginta & PM & be.beautiful \\
\hline & \multicolumn{3}{|l}{ 'Ginta is beautiful.' (Tveit 1997: 14) } \\
\hline
\end{tabular}

As in Vai, the negation pattern of the stative constructions in the Manding-Mokole subbranch are identical or quasi-identical with the negation pattern of the perfective, as illustrated in (15)-(18).

\begin{tabular}{|c|c|c|c|}
\hline \multirow[t]{2}{*}{ (15) } & \multicolumn{3}{|l|}{ Koranko } \\
\hline & yile & $m a ́$ & wùru. \\
\hline & rope.DEF & PM.NEG & be.short \\
\hline & 'The rop & short.' (1 & holz 1987: 110) \\
\hline
\end{tabular}

\begin{tabular}{|l|l|l|l|}
\hline (16) & \multicolumn{3}{|l|}{ Koranko } \\
\hline & $\grave{a}$ & má & nà. \\
\hline & 3SG & PFV.NEG & come \\
\hline & \multicolumn{3}{|l}{} \\
& \multicolumn{3}{|l}{ 'He has not come.' (Kastenholz 1987: 95) } \\
\hline
\end{tabular}

\begin{tabular}{|l|l|l|l|}
\hline (17) & \multicolumn{2}{|l|}{ Xasonga } \\
\hline & silo & man & jan. \\
\hline & road.DEF & PM.NEG & be.far.away \\
\hline & \multicolumn{3}{|l}{ 'The road is not far away.' (Tveit 1997: 14) } \\
\hline
\end{tabular}

\begin{tabular}{|l|l|l|l|l|}
\hline (18) & \multicolumn{4}{|l|}{ Xasonga } \\
\hline & Musa & man & da & yele. \\
\hline & Musa & PFV.NEG & door & open \\
\hline & \multicolumn{5}{|l}{ 'Musa has not opened the door.' (Tveit 1997: 3) } \\
\hline
\end{tabular}


The number of quality verbs varies within the Manding language/dialect cluster. With respect to Bambara, for example, Vydrine (1990) lists 53 items. According to Creissels (1985), twenty three quality verbs constitute the core of quality verbs in Manding. It is interesting to note that none of the quality verbs belonging to the core of this category is attested as a process verb. Moreover, the color terms 'red', 'white' and 'black' do not belong to the core, since they are attested in most Manding variants as process verbs (Creissels 1985: 16-17). Out of the eight quality verbs appearing in the stative in Vai, five have cognate forms among the core quality verbs in Manding, as shown in Table 10. Please note that the "Manding" quality verbs given in Table 10 are actually Standard Bambara forms.

Table 10. Core quality (stative) verbs in Manding and their cognate forms in Vai

\begin{tabular}{|c|c|c|}
\hline $\begin{array}{l}\text { quality (stative) verb in } \\
\text { Manding }\end{array}$ & meaning & $\begin{array}{l}\text { cognate form in Vai always appearing the } \\
\text { stative form }\end{array}$ \\
\hline bòn & be big, large & \\
\hline$c a ́$ & be numerous & \\
\hline dí & be good, pleasing & \\
\hline dógo & be small, narrow & lìj̀ \\
\hline dùn & be deep & \\
\hline fárin & be blazing & \\
\hline fisa & be better & \\
\hline fyén & be light & \\
\hline gírin & be heavy & \\
\hline gwèlen & be hard / difficult & $k p \grave{c l} l \grave{~}$ \\
\hline jàn & be long / far (away) & jày \\
\hline júgu & be bad & jáò \\
\hline kán & be equal & \\
\hline kègun & be clever & \\
\hline kénع & be healthy & \\
\hline kó & $\begin{array}{l}\text { be unpleasant } \\
\text { (senses) }\end{array}$ & \\
\hline kúna & be bitter & \\
\hline màgan & be soft & \\
\hline
\end{tabular}




\begin{tabular}{|l|l|l|}
\hline misen & be small, thin & \\
\hline nyì & be good & nyi \\
\hline sùrun & be short, near & \\
\hline téli & be fast & \\
\hline tími & be sweet & \\
\hline
\end{tabular}

\section{CF. CREISSELS 1985: 12F., 29F.}

The comparison of the encoding of quality (stative) verbs in Central Mande which I have undertaken above raises a question, which is still unresolved: Did the special stative construction in Manding originally contain a predicative marker or not?

In dealing with this question, Creissels (1985) argues that the starting point for what is now in Manding a special stative construction was probably a stative form that did not contain a predicative marker. Creissels notes:

[...] le proto-manding aurait connu dans sa conjugaison une forme stative dépourvue de marque segmentale explicite. (Creissels 1985: 32)

According to Creissels (1985: 30), one might thus imagine that the evolution of a special stative construction in Manding was the result of a specialization process in so-called factative or zero-marked constructions as found in Vai and Yalunka leading to the development of two morphosyntactically different verb classes, that is, quality (stative) verbs and process verbs. Creissels (1985) explains the supposed specialization process as follows:

[...] un nombre limité de verbes auraient cessé de pouvoir fonctionner aux formes autres que la forme stative, alors que la plupart des verbes auraient par contre perdu cette forme - processus qui n'exclut pas un enrichissement ultérieur de la catégorie qui se serait ainsi constituée. (Creissels 1985: 30)

53 The hypothesis put forward by Creissels is without doubt plausible for the development of special stative affirmative constructions containing no predicative marker as found in the Mokole cluster. However, as Creissels (1985: 30) himself concedes, the weak point of this hypothesis is that the special stative affirmative constructions in Manding do have predicative markers whose emergence and possible origin is still unknown.

\section{Closing remarks}

Since quality verbs are sometimes referred as stative verbs in the literature (cf. Creissels (1985), Lüpke (2005)), some comments are in order. ${ }^{6}$ It has to be kept in mind that when we speak of word classes, be it "quality verbs" or "stative verbs", we always have to combine morphosyntactic and semantic criteria. From a semantic point of view quality verbs represent a special set of verbs (like in Manding) referring to properties and qualities which are prototypically associated with adjectives, that is, in Dixon's terms, to semantic types such as "dimension", "age", "value", "color", "physical property", "human propensity" and "speed" (cf. Dixon 1977). Stative verbs - lacking the notions of dynamism and change - semantically represent a larger class that comprises besides quality verbs ('be small') also verbs of perception ('to hear'), 
psychological verbs ('to believe'), relational verbs ('to cost'), locative verbs ('be there') and modal verbs ('to be able').

Against this background quality verbs are thus considered to be cross-cutting with semantically stative verbs. In some languages quality verbs represent a subset of stative verbs, they have no-change-of-state reading and are always [-dynamic]. They typically do not occur in the progressive or as imperatives. This holds true, for example, for the subset of quality verbs in Vai which is exclusively used in the stative construction, but which, in addition to the eight quality verbs, also contains two (stative) modal verbs (see Table 7).

In other cases, however, the restriction on semantic stativity is less strong for quality verbs: They allow for a stative and a dynamic reading depending on the TAM-marking, as has been illustrated for quality verbs in Yalunka (cf. examples (10) and (12)).

Finally, the special stative constructions found in the Manding-Mokole sub-branch can be regarded as exceptions or even counterexamples to Stassen's (1997: 30) Adjective Principle claiming that no language has an encoding strategy which is used exclusively for property concept predicates. Such unique encoding strategies for property concepts are not confined to Central Mande; they are also well attested in the Northwestern branch, more precisely, in Tigemaxo (Bozo) and Duun (Samogo). Tigemaxo has a special affirmative copula $n$ which is only used with predicative adjectives (Blecke 1996: 94), whereas Duun has a special word class "quality verb" which, in contrast to process verbs, is zero-marked in the affirmative (Tröbs 2008b).

\section{BIBLIOGRAPHY}

BLECKE Thomas, 1996, Lexikalische Kategorien und grammatische Strukturen im Tigemaxo (Bozo, Mande), Köln, Köppe.

CREISSELS Denis, 1983, Éléments de grammaire de la langue mandinka, avec la collaboration de Sidia JATTA et Kalifa JOBARTEH, Grenoble, Université des Langues et Lettres.

CREISSELS Denis, 1985, « Les verbes statifs dans les parlers manding », Mandenkan 10, pp. 1-32.

CREISSELS Denis, 2003, " Adjectifs et adverbes dans les langues subsahariennes », in SAUZT P., ZRIBIHERTZ A. (eds.), Typologie des langues d'Afrique et universaux de la grammaire, vol. 1, Paris, Harmattan, pp. 17-38.

CROFT William, 1990, Typology and universals, Cambridge, Cambridge University Press.

DIXON R.M.W., 1977, “Where have all the adjectives gone?”, Studies in Language 1, pp. 19-80.

DIXON R.M.W., 2004, "Adjective classes in typological perspective", in DIXON R.M.W., AIKHENVALD A.Y. (eds.), Adjective classes. A cross-linguistic typology, Oxford, Oxford University Press, pp. 1-49. ELDERS Stefan, TRÖBS Holger, METTOUCHI Amina. Questionnaire for quality verbs in African languages. http://www.eva.mpg.de/lingua/tools-at-lingboard/pdf/Questionnaire-Quality-Verbs-for-EVAMPG.pdf (Accessed 2014-10-22.) 
GIVÓN Talmy, 1984, Syntax: a functional-typological introduction, vol. 1, Amsterdam - Philadelphia, Benjamins.

HEYDORN Richard W., 1971, “The Vai language in Liberia”, Afrika und Übersee 54(3), pp. 149-205. [Ms 1934].

JANSE Jacqueline, 1998, MJgJfin: Eléments de description grammaticale, Boké, Mission évangélique réformée néerlandaise.

KASTENHOLZ Raimund, 1987, Das Koranko. Ein Beitrag zur Erforschung der Nord-Mande-Sprachen, Köln Bonn, Mundus.

KASTENHOLZ Raimund, 1996, Sprachgeschichte im West-Mande: Methoden und Rekonstruktionen, Köln, Köppe.

KASTENHOLZ Raimund, "Klingenheben's collection of Vai lexical data adapted and edited by Raimund KASTENHOLZ" [unpublished manuscript, 260 pp.].

KLINGENHEBEN August, 1933, "Der Bau der Sprache der Vai in Westafrika”, Nachrichten von der Gesellschaft der Wissenschaften zu Göttingen, Philologisch-Historische Klasse III, 9, pp. 373-404. KUZNETSOVA Olga, 2004, Tipy minimalnych vyskazyvanij v jazyke vai. [Simple sentence types in Vai] St. Petersburg, St. Petersburg State University. Ms.

LEWIS M.P., (ed.), 2009, Ethnologue: Languages of the world. $16^{\text {th }}$ edn. Dallas, SIL.

LÜPKE Friederike, 2005, A grammar of Jalonke argument structure (MPI series in psycholinguistics), University of Nijmegen (Doctoral dissertation).

PUSTET Regina, 2003, Copulas, Universals in categorization of the lexicon, Oxford, Oxford University Press.

SASSE Hans-Jürgen, 1993, "Syntactic categories and subcategories”, in JACOBS J. et al. (eds.), Syntax: An international handbook of contemporary research, Berlin - New York, de Gruyter, pp. 646-686.

STASSEN Leon, 1997, Intransitive Predication, Oxford, Clarendon Press.

TRÖBS Holger, 2008a, « Introduction in Tröbs Holger, ROTHMALER Eva, WINKELMANN Kerstin (eds.), La qualification dans les langues africaines, Köln, Köppe, pp. 7-12.

TRÖBS Holger, 2008b, « Duun », in Tröbs Holger, ROTHMALER Eva, WINKELMANN Kerstin (eds.), La qualification dans les langues africaines, Köln, Köppe, pp. 71-86.

TRÖBS Holger, 2009, Sprachtypologie, TAM-Systeme und historische Syntax im Manding (West-Mande), Köln, Köppe.

TVEIT Harald, 1997, Grammaire de la langue khassonke, Bamako, Mission Protestante Norvégienne. VYDRIN Valentin, 1990, « Les adjectifs prédicatifs en bambara », Mandenkan 20. pp. 47-89. VYDRIN Valentin, 2009, « Esquisse de la langue lélé (groupe mokolé) », Mandenkan 45, pp. 29-104. WELMERS William E., 1973, African language structures, Berkeley, University of California Press. WELMERS William E., 1976, A grammar of Vai. Berkeley - Los Angeles - London, University of California Publications. 


\section{NOTES}

1. (l) represents the morpheme internal alternation between [l] and zero.

2. This definition of adjectives was also used in the context of the German/French collaborative projects "Eigenschaftskonzepte in westafrikanischen Sprachen" (University of Bayreuth) and "Typologie des adjectifs et de la qualification dans les langues africaines" (LLACAN, CNRS) (cf. Tröbs 2008a).

3. The terminology indicated in square brackets is mine.

4. The last three verbs are included by Welmers although their tones are not low throughout. Welmers (1976: 95-96) notes: "The lexical tones of many of the qualificatives cannot be determined; they have been recorded only in this construction, and perhaps do not occur in other constructions in which their lexical tone would be expected to occur."

5. Within the Manding language/dialect cluster, Mandinka represents a special case in that it has no stative construction. However, Mandinka has a (kind of) factative construction marked with the suffix -ta (cf. Creissels 1983: 105-109).

6. The following argumentation is taken from the "Questionnaire for quality verbs in African languages" elaborated by Stefan Elders, Holger Tröbs and Amina Mettouchi. The questionnaire is meant as a tool for field workers to guide the identification and description of verbs expressing property concepts in African languages.

\section{ABSTRACTS}

This paper investigates the different encoding strategies used for the expression of property concepts in Vai. Following Stassen (1997), it is shown that, viewed cross-linguistically, Vai represents an extreme case in that it makes use of four different encoding strategies (two nonverbal and two verbal ones). The multiple split of the property concept words in Vai is examined by drawing on the semantic types of Dixon $(1977 ; 2004)$ as well as Givón's (1984) Time Stability Scale. Moreover, the two verbal strategies, that is, the factative and the stative construction, are discussed from a Central Mande perspective.

Le but général de cet article est de traiter en détails les différentes stratégies qui sont employées en Vai pour exprimer les prédicats de propriété. Comme l'a fait remarquer Stassen (1997) en discutant l'expression de la qualification du point de vue typologique, le trait le plus saillant du Vai est l'emploi de quatre stratégies différentes (deux stratégies non-verbales et deux stratégies verbales). L'encodage des mots de propriété est examiné en considérant les types sémantiques de Dixon $(1977$; 2004) et le concept de “time-stability” proposé par Givón (1984). De plus, les deux stratégies verbales (le factatif et le statif) sont étudiées dans une perspective comparatiste des langues du groupe Mandé-Central.

В СТАТЬЕ РАССМАТРИВАЮТСЯ РАЗЛИЧНЫЕ СТРАТЕГИИ ВЫРАЖЕНИЯ КАЧЕСТВЕННЫХ ЗНАЧЕНИЙ В ВАИ. ДЕМОНСТРИРУЕТСЯ, ЧТО В РАМКАХ ТИПОЛОГИЧЕСКОЙ МОДЕЛИ СТАССЕНА [Stassen 1997], ВАИ ПРЕДСТАВЛЯЕТ СОБОЙ КРАЙНИЙ СЛУЧАЙ, ПОСКОЛЬКУ ИСПОЛЬЗУЕТ ЧЕТЫРЕ РАЗЛИЧНЫЕ СТРАТЕГИИ КОДИРОВАНИЯ (ДВЕ НЕГЛАГОЛЬНЫЕ И ДВЕ ГЛАГОЛЬНЫЕ). МНОЖЕСТВЕННАЯ РАСЩЕПЛЁННОСТЬ В СФЕРЕ ВЫРАЖЕНИЯ КАЧЕСТВЕННЫХ ЗНАЧЕНИЙ В ВАИ РАССМАТРИВАЕТСЯ В СВЕТЕ ВЫДЕЛЯЕМЫХ ДИКСОНОМ [Dixon 1977; 2004] И ГИВОНОМ [Givón 1984] ШКАЛЫ ВРЕМЕННОЙ 
УСТОЙЧИВОСТИ. КРОМЕ ТОГО, ДВЕ ГЛАГОЛЬНЫЕ СТРАТЕГИИ (ФАКТАТИВНАЯ И СТАТИВНАЯ КОНСТРУКЦИИ) ОБСУЖДАЮТСЯ В СВЕТЕ ПЕРСПЕКТИВЫ ЦЕНТРАЛЬНОЙ ГРУППЫ МАНДЕ.

\section{INDEX}

Subjects: vai, langues mandé centrales, langues mandé

Mots-clés: prédicats de propriété, qualification, adjectifs, verbes statifs, verbes de qualité

Keywords: Property Concepts, Qualification, Stative Verbs, Quality Verbs, Adjective Principle, Vai, Central Mande, Mande

motsclesru КАЧЕСТВЕННЫЕ ЗНАЧЕНИЯ, КАЧЕСТВЕННОСТЬ, СТАТИВНЫЕ ГЛАГОЛЫ, КАЧЕСТВЕННЫЕ ГЛАГОЛА, ВАИ, ЦЕНТРАЛЬНЫЕ МАНДЕ, МАНДЕ

\section{AUTHOR}

\section{HOLGER TRÖBS}

University of Mainz

troebs@uni-mainz.de 